\title{
PENGARUH KEPEMILIKAN INSTITUSIONAL, PROFITABILITAS, UKURAN PERUSAHAAN TERHADAP KEBIJAKAN HUTANG PERUSAHAAN DI INDONESIA
}

\author{
Elly Astuti \\ elly.astuti@gmail.com
}

\begin{abstract}
ABSTRAK
Penelitian ini bertujuan untuk melakukan pengujian secara empiris terhadap pengaruh kepemilikan institusional, profitabilitas dan ukuran perusahaan terhadap kebijakan hutang pada perusahaan yang listing di BEI tahun 2012. Metode pengambilan sampel dengan menggunakan purposive sampling dengan jumlah sampel akhir 237 perusahaan. Teknik analisis yang digunakan adalah regresi linear berganda. Hasil penelitian menunjukkan bahwa kepemilikan institusional tidak berpengaruh terhadap kebijakan hutang. Sedangkan profitabilitas dan ukuran perusahaan berpengaruh positif terhadap kebijakan hutang.
\end{abstract}

Kata kunci : kepemilikan institusional, profitabilitas, ukuran perusahaan kebijakan hutang.

\section{PENDAHULUAN}

Pendanaan merupakan salah satu aspek terpenting dalam perusahaan karena pada dasarnya perusahaan memerlukan dana demi keberlangsungan kegiatan operasionalnya. Sumber pendanaan tersebut dapat diperoleh dari pihak internal maupun eksternal. Sumber dana internal berasal dari laba ditahan dan depresiasi. Sedangkan modal eksternal berasal dari kreditur, pemilik ataupun pemegang saham lainnya di perusahaan (Helda ; 2009).
Sumber dana dari kreditur merupakan hutang bagi perusahaan. Hutang bagaikan dua sisi mata uang bagi perusahaan yaitu memiliki dampak positif maupun dampak negatif. Pada tingkat tertentu, hutang mampu menciptakan suatu sistem pengawasan terhadap perusahaan serta dapat digunakan untuk penghematan pajak sehingga dapat meningkatkan nilai perusahaan. Pada sisi lain, jumlah hutang yang terlalu tinggi akan mengakibatkan semakin tingginya bancrupty cost. Untuk itu, manajer keuangan selaku agen yang 
Pengaruh Kepemilikan Institusional, Profitabilitas,

Ukuran Perusahaan Terhadap Kebijakan Hutang

Perusahaan Di Indonesia

diberi wewenag untuk mengelola perusahaan, harus mempertimbangkan financing mix terbaik bagi perusahaan.

Namun demikian, keputusan manajer untuk menentukan financing mix tersebut seringkali menimbulkan konflik dengan prinsipal. Jensen Meckling (dalam Muhammad Faizal ; 2004) mengungkapkan bahwa penyebab timbulnya konflik antara manajer dengan prinsipal adalah pembuatan keputusan yang berkaitan dengan sumber pendanaan (financing decision) dan keputusan investasi (investment decision).

Salah satu metode yang sering disarankan untuk mengurangi konflik kepentingan antara manager dengan prinsipal adalah melalui kepemilikan manajerial. Namun demikian, tingkat kepemilikan manajerial di Indonesia pada tahun 2012 sangat kecil sehingga pengaruhnya untuk mengurangi konflik kepentingan tersebut dirasa kurang signifikan. Wahidahwati (2002) menyatakan bahwa kepemilikan institusional dapat melakukan subtitusi terhadap kepemilikan manajerial. Oleh karena itu dalam penelitian ini ingin menguji pengaruh kepemilikan institusional terhadap kebijakan hutang perusahaan-perusahaan di Indoensia pada tahun 2012.

Beberapa peneliti terdahulu telah melakukan studi empirik untuk menguji hubungan antara kepemilikan Jurnal Akuntansi dan Pajak Vol. 15 No. 02, Januari 2014
ISSN : 1412-6029X

institusional terhadap kebijakan hutang perusahaan. Namun demikian, sampel yang digunakan hanya mengambil beberapa sektor perusahaan di BEI dengan data time series. Untuk itu, pada penelitian ini digunakan 1 tahun pengamatan dengan melibatkan seluruh perusahaan listing di BEI tahun 2012 dengan metode pengambilan sampel purposive sampling.

\section{TELAAH LITERATUR DAN}

\section{PENGEMBANGAN HIPOTESIS}

Teori Keagenan (Agency Theory)

Teori keagenan (Agency Theory) dalam (William R. Scott ; 2009) merupakan salah satu cabang game theory yang mempelajari skema kontrak untuk memotivasi agen agar bertindak sebagai representasi dari prinsipal ketika kepentingan agen atau lainnya bertentangan dengan kepentingan investor. Prinsip utama teori ini adalah adanya kontrak kerjasama antara agen dengan prinsipal, dimana agen diberikan wewenang penuh untuk mengelola asset ekonomis prinsipal guna mencapai kemakmuran.

Salah satu hipotesis dalam teori tersebut mengemukakan bahwa manajemen dalam mengelola perusahaan cenderung akan mementingkan kepentingan pribadinya karena adanya asymetri information dengan prinsipal. Salah satu upaya yang dapat dilakukan untuk 
mengurangi tidakan oportunistik manajer adalah melalui diversifikasi struktur kepemilikan.

\section{Kepemilikan Institusional}

Kepemilikan institusional adalah kepemilikan saham perusahaan yang dimiliki oleh institusi atau lembaga seperti perusahaan asuransi, bank, perusahaan investasi dan kepemilikan institusi lain (Dwi Sukirni, 2012). Kepemilikan institusi berperan penting dalam mengurangi konflik keagenan karena mereka memiliki dorongan untuk memonitor aktivitas yang dilakukan manajer untuk melindungi investasinya (Rahmawati, 2012). Sehingga semakin tinggi tingkat kepemilikan institusional, voting power dan pengaruh mereka terhadap kebijakan-kebijakan manajer semakin kuat. Oleh karena itu, rasio hutang perusahaan diprediksikan berhubungan negatif dengan kebijakan hutang perusahaan.

\section{H1 : Kepemilikan institusional berpengaruh negatif terhadap kebijakan hutang perusahaan}

\section{Teori Struktur Modal (Capital Structure Theory)}

Struktur modal menggambarkan perimbangan pendanaan antara hutang dengan modal perusahaan. Sedangkan teori struktur modal adalah teori yang menjelaskan financing mix antara hutang dengan modal yang dapat memaksimalkan nilai perusahaan. Struktur modal dapat dikatakan optimum bagi perusahaan jika perimbangan antara hutang dengan modal yang menghasilkan Weight Averrage Cost of Capital (WACC) terendah.

Dwi Sukirni (2012) menyatakan dalam trade off theory, penetuan struktur modal yang optimal dipertimbangkan beberapa faktor antara lain pajak, biaya keagenan (agency costs) dan biaya kesulitan keuangan tetapi tetap mempertahankan asumsi efisiensi pasar dan symetric information sebagai imbangan dan manfaat penggunaan hutang. Oleh karena itu, dalam penggunaan hutang untuk mendanai kegiatan perusahaan harus mempertimbangkan selisih antara penghematan pajak yang dapat dilakukan dengan biaya hutang (bunga) yang harus dibayarkan.

\section{Profitabilitas}

Profitabilitas

mencerminkan kemampuan perusahaan memperoleh laba sehingga mampu mendanai kegiatan investasi perusahaan jangka panjang. Myers (1984) dalam Rizka dan Ratih (2009) perusahaan dalam melakukan pendanaan kegiatan investasi harus memperhatikan pecking order yaitu urutan penggunaan dana yang dimulai dari laba ditahan yang kemudian diikuti oleh hutang dan ekuitas. Oleh karena itu, semakin tinggi profitabilitas 
perusahaan, akan mengurangi tingkat hutang.

H2 : Profitabilitas berpengaruh negatif terhadap kebijakan hutang perusahaan.

\section{Ukuran Perusahaan (Size)}

Perusahaan yang besar memiliki aktiva yang cukup besar yang dapat dipergunakan sebagai jaminan untuk melakukan hutang (Elva Nuraina ; 2012). Hal ini didukung oleh Short dan Kisey (1999) dalam Sulong et al (2013) yang menyatakan bahwa perusahaan besar memiliki akses yang luas terhadap pendaan internal maupun eksternal karena ukuran perusahaan merupakan salah satu penentu kinerja keuangan perusahaan. Sehingga semakin besar ukuran perusahaan, diprediksikan memiliki tingkat hutang yang semakin tinggi.

H3 : ukuran perusahaan berpengaruh positif terhadap kebijakan hutang perusahaan.

\section{METODE PENELITIAN}

\section{Sampel dan Data Penelitian}

Sampel yang digunakan dalam penelitian ini adalah perusahaanperusahaan yang terdaftar di BEI pada tahun 2012. Perusahaan dipilih dengan menggunakan metode Purposive Sampling dengan metode pengambilan sampel Cross Sectional.

Beberapa kriteria data yang dijadikan sampel adalah sebagai berikut :

Jurnal Akuntansi dan Pajak Vol. 15 No. 02, Januari 2014
1. Perusahaan listing di BEI pada tahun 2012.

2. Perusahaan menerbitkan laporan keuangan tahunan audit dengan periode laporan 31 Desember.

3. Ada presentase saham yang dimiliki oleh institusi lokal.

4. Memiliki profitabilitas positif.

\section{Definisi Operasional Variabel}

1. Kepemilikan insttitusional merupakan presentase kepemilikan institusi lokal dari seluruh jumlah saham ybiasa yang beredar.

2. Profitabilitas diukur dari Earning per Share perusahaan (Sulong et al, 2013).

3. Ukuran Perusahaan (Size) merupakan natural log of total assets. Variabel ini diharapkan mempunyai koefisien yang positif sehingga semakin terdiversifikasi perusahaan, akan memperkecil kemungkinan untuk bangkrut karena mampu memenuhi kewajibannya (Dyah Sih Rahayu, 2005)

4. Kebijakan hutang diukur dengan mengunakan Debt to Equity Ratio (DER) yang merupakan perbandingan antara total hutang dengan total ekuitas dari saham biasa perusahaan yang mengggambarkan kebijakan struktur pendanaan yang diambil perusahaan (Dwi Sukirni, 2012) 


\section{Analisis Data}

Metode analisis yang digunakan dalam penelitian ini adalah analisis regresi linear berganda. Untuk menguji hipotesis akan digunakan model sebagai berikut :

$$
\text { Kebijakan Hutang }=\alpha+\beta_{1} \text { Institusional }+\beta_{2} \text { Profitabilitas }+\beta_{3} \text { Size }+\varepsilon
$$

\section{HASIL DAN PEMBAHASAN}

Berdasarkan kriteria yang telah ditentukan sebelumnya, hasil pengambilan sampel penelitian adalah sebagai berikut :

Tabel Hasil Pengambilan Sampel

\begin{tabular}{lc}
\hline \multicolumn{1}{c}{ Kriteria Sampel } & Jumlah \\
\hline Perusahaan listing di BEI pada tahun 2012 & 478 \\
Laporan keuangan audit tidak ada / data tidak & 43 \\
lengkap & \\
Periode laporan tidak 31 Desember & 6 \\
Tidak ada presentase kepemilikan institusi & 95 \\
lokal & \\
Profit bernilai negatif / ekstrim & 19 \\
Data Outlier & 78 \\
\hline Jumlah sampel & 237 \\
\hline
\end{tabular}

Sumber : Data diolah peneliti

Dari tabel diatas, diketahui bahwa jumlah observasi yang dilakukan pada penelitian ini berjumlah 237 perusahaan. Data penelitian diperoleh dari laporan keuangan audit tahun 2012 yang dipublikasikan BEI pada www.idx.co.id. Pengujian hipotesis dilakukan dengan menggunakan software SPSS 18.0 for windows.

Hasil statistik deskriptif untuk masing-masing variabel pada penelitian ini adalah sebagai berikut : 
Statistik Deskriptif

\begin{tabular}{|c|c|c|c|}
\hline \multicolumn{4}{|c|}{ Descriptive Statistics } \\
\hline & Mean & Std. Deviation & $N$ \\
\hline DER & 4.04522288 & 4.179585063 & 237 \\
\hline $\begin{array}{l}\text { Inst_lo } \\
\mathrm{k}\end{array}$ & .50161238 & .269253470 & 237 \\
\hline $\begin{array}{l}\text { Profit } \\
\text { Size }\end{array}$ & $\begin{array}{r}103.5151 \\
28.01990402 \\
\end{array}$ & $\begin{array}{r}176.71559 \\
1.433308225 \\
\end{array}$ & $\begin{array}{l}237 \\
237\end{array}$ \\
\hline \multicolumn{4}{|l|}{ Ket : } \\
\hline $\begin{array}{l}\mathrm{DER} \\
(\mathrm{eps})\end{array}$ & $=$ Debt to Equity Ratio & Profit $=$ Profitabiltas & perusahaan \\
\hline $\begin{array}{r}\text { Inst_Lok } \\
=\end{array}$ & $\begin{array}{l}= \\
=\text { Ukuran Perusahaan }\end{array}$ & Kepemilikan Institusi & _okalSize \\
\hline
\end{tabular}

\section{Uji Asumsi Klasik}

Uji Normalitas data dilakukan dengan melihat probability plot sebagai berikut :

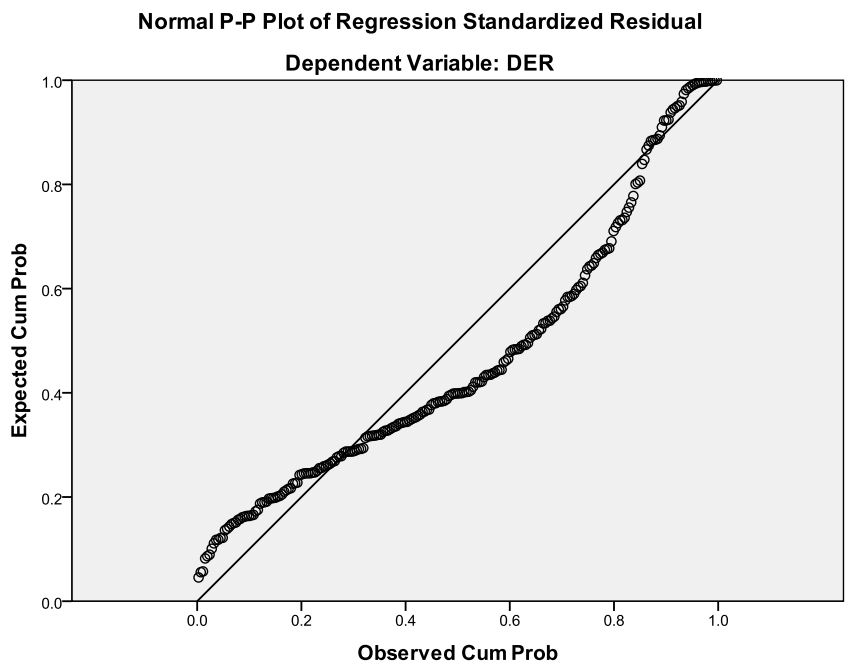

Berdasarkan normal probability plot tersebut diketahui bahwa sebaran data berada di sekitar (mendekati) garis normal. Maka diasumsikan bahwa data dalam penelitian ini telah terdistribusi dengan normal.

Hasil uji multikolinearitas tersaji pada tabel berikut : 
Tabel 3. Uji Multikolinearitas

\begin{tabular}{|c|c|c|c|}
\hline Variabel & Tolerance & VIF & Keterangan \\
\hline Inst_Lok & 0,993 & 1,007 & $\begin{array}{l}\text { Tidak terdapat } \\
\text { multikolinearitas }\end{array}$ \\
\hline Profit & 0,966 & 1,035 & $\begin{array}{l}\text { Tidak terdapat } \\
\text { multikolinearitas }\end{array}$ \\
\hline Size & 0,964 & 1,037 & $\begin{array}{l}\text { Tidak terdapat } \\
\text { multikolinearitas }\end{array}$ \\
\hline
\end{tabular}

Sumber data diolah peneliti

Hasil uji autokorelasi dengan menggunakan uji durbin watson diperoleh nilai 1,784. Hasil tersebut mendekati +2 sehingga dapat disimpulkan bahwa tidak terjadi autokorelasi pada persamaan regresi.
Hasil uji heterokedastisitas persamaan regresi menunjukkan bahwa titik titik tersebar di bawah dan diatas angka nol sebagai berikut:

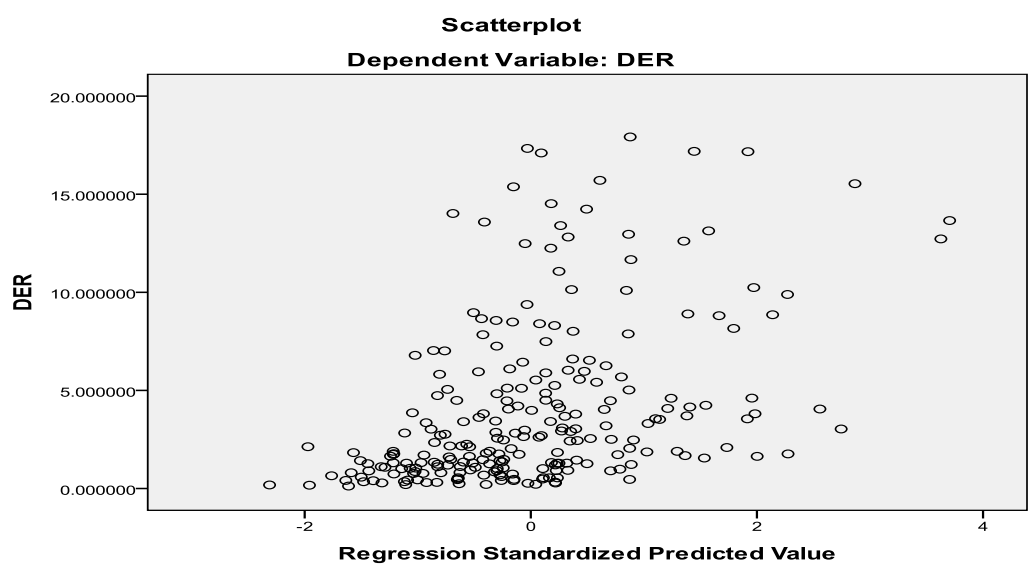

Dari gambar tersebut, dapat disimpulkan bahwa tidak terjadi heterokesdaktisitas dalam persamaan regresi yang digunakan.

\section{Uji Hipotesis}

Hasil uji t untuk mengetahui pengaruh dari masing-masing variabel dependen adalah sebagai berikut : 
Tabel Hasil Uji Hipotesis

\begin{tabular}{|c|c|c|c|c|}
\hline Variabe & $B$ & Sig. & Keputusan & \\
\hline Inst_Lok & 0,899 & 0,329 & $\mathrm{H}_{1}$ tidak dapat diterin & \\
\hline Profit & 0,006 & 0,000 & $\mathrm{H}_{2}$ tidak dapat diterin & \\
\hline Size & 0,853 & 0,000 & $\mathrm{H}_{3}$ diterima & \\
\hline $\begin{array}{l}\text { Ket : } \\
\text { DER }\end{array}$ & Debt to Equity Ratio & \multicolumn{3}{|c|}{ Profit $=$ Profitabiltas perusahaan $(\mathrm{eps})$} \\
\hline $\begin{array}{r}\text { Inst_Lok }= \\
\text { Uku }\end{array}$ & $\begin{array}{l}= \\
\text { uran Perusa }\end{array}$ & \multicolumn{2}{|c|}{ Kepemilikan Institusi LokalSize } & $=$ \\
\hline
\end{tabular}

Berdasarkan hasil uji hipotesis pada tabel 4 dapat dilihat bahwa variabel Institusi lokal bertanda positif. Hal ini mengindikasikan kenaikan tingkat kepemilikan institusi lokal memiliki pengaruh searah dengan kebijakan hutang perusahaan. Namun demikian, jika dilihat dari tingkat signifikansi uji hipotesis yang tidak menerima $\mathrm{H}_{1}$, kemungkinan disebabkan oleh pengaruh krisis global yang terjadi pada tahun 2012 yang mengakibatkan penarikan modal secara besar-besaran karena iklim investasi yang tidak menentu. Sehingga perusahaan banyak yang melakukan pendanaan dari sumber hutang dan membuat tingkat kepemilikan institusi kurang berpengaruh terhadap kebijakan hutang perusahaan.

Hasil uji $\mathrm{H}_{2}$ tidak dapat diterima karena nilai profit bertanda positif. Hal ini bertentangan dengan pecking order theory yang menyatakan bahwa sumber pendanaan utama perusahaan dimulai dari laba di tahan. Kondisi tersebut kemungkinan disebabkan oleh semakin tinggi profitabilitas yang dimiliki perusahaan, manajemen semakin yakin dengan kemampuannya untuk mencapai kinerja yang optimal sehingga mampu membayar hutang jangka panjangnya. Hasil penelitian ini mendukung penelitian Rizka dan Ratih (2009). Kemudahan akses perusahaan untuk mendapatkan pendanaan dari hutang memberikan sinyal positif kepada investor akan kinerja masa 
depan yang lebih baik sehingga mampu meningkatkan nilai perusahaan. Oleh karena itu, pada kondisi perusahaan yang memiliki tingkat profitabilitas cukup tinggi dengan kesempatan investasi yang terbatas, manajemen lebih menyukai sumber pendanaan dari hutang.

Hasil uji $\mathrm{H}_{3}$ menunjukkan hasil yang signifikan positif. Hal ini mengindikasikan semakin besar perusahaan, memberikan kemudahan akses pencarian dana dari sumber hutang karena perusahaan mempunyai collateral assets yang semakin besar. Hasil penelitian ini mendukung penelitian dari Cristianti (2006) yang menyatakan semakin besar aktiva tetap sebagai bagian perusahaan, akan mempermudah akses pendanaan dari sumber hutang.

\section{SIMPULAN}

Berdasarkan hasil analisis dan pembahasan yang telah diuraikan, dapat disimpulkan bahwa kepemilikan institusional tidak berpengaruh terhadap kebijakan hutang perusahaan. Sedangkan profitabilitas dan ukuran perusahaan berpengaruh positif terhadap kebijakan hutang perusahaan.

Beberapa keterbatasan dalam penelitian ini adalah periode penelitian hanya satu tahun sehingga tidak dapat digunakan untuk memprediksikan kecenderungan dalam jangka panjang. Disamping itu, dalam penelitian ini hanya menggunakan tiga

variabel. Dimungkinkan masih banyak variabel lain yang turut mempengaruhi kebijakan hutang perusahaa seperti growth, free cash flow, resiko bisnis, kesempatan investasi dan lain-lain.

Berdasarkan

keterbatasan

penelitian ini, disarankan untuk penelitian mendatang yang akan melakukan penelitian dengan topik yang sama dapat memperpanjang periode penelitian untuk mengungkapkan kecenderungan kebijakan hutang dalam jangka panjang. Selain itu, juga dapat menambahkan variabel-variabel lainnya yang dimungkinkan berpengaruh terhadap kebijakan hutang perusahaan. 


\section{DAFTAR PUSTAKA}

Augustine, Yvonne dan Robert Kristaung. 2013.Metodologi Penelitian Bisnis dan Akuntansi. Dian Rakyat. Jakarta

Christianti, Ari. 2006. Penentuan Perilaku Kebijakan Struktur Modal Pada Perusahaan Manufaktur Di Bursa Efek Jakarta: Hipotesis Static Trade Off Atau Pecking Order Theory. SNA IX : Ikatan Akuntansi Indonesia.

Dustin Bhakti, Adam. Pengaruh Struktur Kepemilikan Manajerial dan Kepemilikan Institusional Terhadap Kebijakan Hutang Perusahaan Manufaktur Yang Terdaftar di BEI Tahun 20092011. Universitas Brawijaya. Malang. Google Scholar diakses pada tanggal 12 Maret 2014.

Endah Erdiana, Helda. Analisis Pengaruh Firm Size, Business Risk, Profitability, Assets Growth, Dan Sales Growth Terhadap Struktur Modal (Studi Kasus Pada Perusahaan Real Estate And Property yang Terdaftar di BEI periode 2005-2008). Universitas Diponegoro. Semarang. Google scolar diakses pada tanggal 12 Maret 2013.

Faisal, Muhamad, 2004. Analisis Pengaruh Free Cash Flow, Set Kesempatan Kepemilikan Manajerial dan Ukuran Perusahaan Terhadap Kebijakan Hutang (Studi Empiris Pada

Perusahaan-Perusahaan
Sektor Industri Manufaktur di BEJ). Thesis. Universitas Diponegoro. Semarang.

Ghozali, Imam. 2013. Aplikasi Analisis Multivariate dengan Program IBM SPSS 21 Update PLS Regresi. Badan Penerbit Universitas Diponegoro. Semarang

Noor Rahmayani, Hanindita. 2008. Pengaruh Kepemilikan Institutional dan Karakteristik Keuangan Terhadap Keputusan Pendanaan (Studi Empiris Pada Sektor Properti dan Real Estate di BEI Tahun 2001 - 2007). Thesis. Universitas Diponegoro. Semarang.

Nuraina, Elva. 2012. Pengaruh Kepemilikan Institusional dan Ukuran Perusahaan Terhadap Kebijakan Hutang dan Nilai Perusahaan (Studi Pada Perusahaan Manufaktur yang Terdaftar di BEI). Jurnal Bisnis dan Ekonomi (JBE), September 2012, Hal. $110-125$

Putri, Rizka dan Ratih Handayani.2009. Pengaruh Kepemilikan Kepemilikan Deviden, Manajerial, Institusional,, Pertumbuhan

Perusahaan, Free Cash Flow, dan Profitabilitas Terhadap Kebijakan Hutang Perusahaan. Jurnal Bisnis dan Akuntansi Vo. 11 No. 3 Desember 2009. Hal 189-207 